DOI: https://doi.org/10.15688/jvolsu3.2017.3.14

UDC 332.12:330.1

LBC 65.012.2+65.9(2Poc) $-5+65.049(2)$

\title{
THE HETEROGENEITY OF THE REGION'S ECONOMIC SPACE: CONCEPTUAL APPROACHES AND IDENTIFICATION METHODS
}

\author{
Elena O. Mirgorodskaya \\ Don State Technical University, Rostov-on-don, Russian Federation \\ Sergey A. Sukhinin \\ Don State Technical University, Rostov-on-don, Russian Federation
}

\begin{abstract}
The economic space of the region is the medium of relations of economic entities located on its territory. It is characterized by heterogeneity, due to the structured interaction of endogenous factors of production and the asynchrony of economic processes. The territorial structure of the economic space can correspond to several models, but a centre-periphery model can be considered the most widespread.

The research relevance consists in the essence of the heterogeneity of the economic space of the region as one of its main properties, reflecting its differentiation. The authors analyze the approaches to interpreting the heterogeneity of the economic space in the works of Russian and foreign economists and identify the main types of territorial models of the economic space. The algorithm for detecting the heterogeneity of economic space of a region based on a centre-periphery model is presented. A necessary and sufficient set of socio-economic indicators is proposed in the form of qualitative and quantitative indicators characterizing the region. The application of these indicators is justified in the context of the limited statistical base characterizing the socio-economic parameters of the region.

The approbation of this method of revealing the territorial structure of the economic space is carried out according to the data of the socio-economic development of the Rostov region, in which three spatially expressed hierarchical units are distinguished: the center, the periphery, and the semi-periphery. The authors determine the composition and characteristics of each of these spatial zones and their relationship, reveal problem fields and prospects for their future development based on existing imbalances and current potential.

Key words: economic space, territorial heterogeneity, centre-periphery structure, socio-economic parameters, quantitative indicators, Rostov region, polycentricism, hinterland.
\end{abstract}

УДК 332.12:330.1

ББК 65.012.2+65.9(2Рoc)-5+65.049(2)

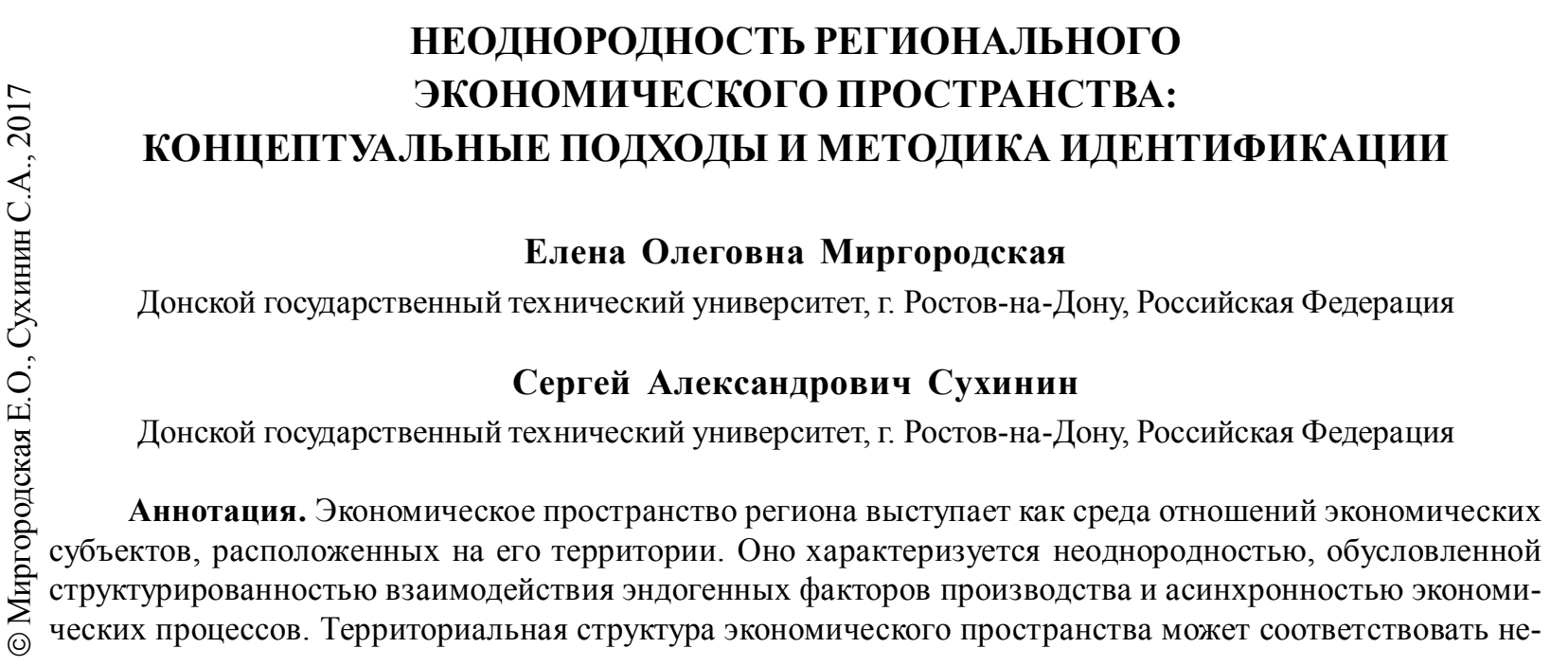


скольким моделям, но наиболее распространенной может считаться центро-периферийная модель его устройства.

Сущность исследования состоит в рассмотрении неоднородности экономического пространства региона как одного из главных его свойств, отображающих его дифференциацию. Анализируются подходы в трактовке неоднородности экономического пространства в работах отечественных и зарубежных экономистов, указываются основные типы территориальных моделей экономического пространства. Излагается алгоритм выявления неоднородности экономического пространства региона на основе центро-периферийной ее модели, определяется необходимый и достаточный для этого набор социально-экономических индикаторов в виде качественных и количественных показателей, характеризующих регион. Обосновывается применение данных индикаторов в условиях ограниченности статистической базы, характеризующей социальноэкономические параметры региона.

Апробация указанной методики выявления экономического пространства проведена по данным социально-экономического развития Ростовской области, в которой выделены три пространственно выраженные иерархические единицы - центр, периферия и полупериферия. Определены состав и особенности каждой из данных пространственных зон, установлены их соотношения, выявлены проблемные поля и перспективы их дальнейшего развития, исходя из сложившихся диспропорций и имеющегося потенциала.

Ключевые слова: экономическое пространство, территориальная неоднородность, центро-периферийная структура, социально-экономические параметры, количественные показатели, Ростовская область, полицентричность, хинтерланд.

Экономическое развитие любого региона в той или иной степени характеризуется пространственной неоднородностью. Она выражается в различиях степени проявления экономических и социальных процессов на определенной территории, когда создание товаров и услуг все в большей мере концентрируется в небольшом числе центров, втягивающих в свою орбиту финансовые и трудовые ресурсы остальной части территории, выступающей для них периферией. Неоднородность экономического пространства является следствием дифференциации экономического развития страны в целом и ее отдельных регионов. Она обусловлена комплексом факторов и условий, которые представлены изначально или сложились исторически в том или ином регионе. Именно они объясняют приуроченность конкретных отраслей к отдельным местам территории, а следовательно, различия от места к месту.

Наиболее остро проблемы неоднородности экономического пространства проявляются в крупных по площади территории и численности населения странах, отличающихся значительной дифференциацией социальноэкономических процессов и явлений, а следовательно, обладающих контрастными различиями пространства. Еще более глубоко и ярко выражается неоднородность экономического пространства на уровне отдельных регионов страны. Целью данной статьи является обоб- щение особенностей теоретических подходов, раскрывающих понимание неоднородности экономического пространства и обоснование методики выявления данного свойства развития региона.

Неоднородность является одним из основополагающих свойств экономического пространства. Оно отображается в виде его дифференциации, возникшей под влиянием множества факторов и условий, воздействующих на объекты, выступающие структурными элементами пространства [7].

Интерес к проблемам экономического пространства и исследование его свойств, в том числе и неоднородности, в работах отечественных и зарубежных ученых позволяют констатировать, что к настоящему времени сложилось несколько направлений развития теоретических и методологических аспектов этой теории, что свидетельствует об актуальности проблемы. С другой стороны, еще не выработаны единые концептуальные основы, позволяющие интегрировать уже разработанные положения теории неоднородности экономического пространства в целостную и стройную логическую схему [1-5; 12-14].

Неоднородность экономического пространства имеет качественное и количественное выражение. Оно обусловлено процессом качественного преобразования пространства, его переходом из одного состояния в другое, протекает с определенной ско- 
E.О. Миргородская, С.А. Сухинин. Неоднородность регионального экономического пространства

ростью и интенсивностью. В разных точках пространства одни и те же процессы могут протекать с разной скоростью, причем в некоторых случаях она варьируется в довольно широком диапазоне. Эти различия и формируют неоднородность экономического пространства как степень проявления его свойств и качеств по-разному в разных точках [3]. Исходя из этих теоретических подходов неоднородность экономического пространства региона может быть прослежена посредством нескольких территориально выраженных моделей, которые позволяют установить тип территориальной структуры. Среди них обычно выделяют (рис. 1):

а) центро-периферийный (концентрический) тип, основанный на четком выделении доминантного экономического центра (промышленного, административного) и периферийной зоны по мере удаления от него;

б) полицентрический (квадратно-прямоугольный) тип, свойственный для равнинных территорий с длительной историей развития, где экономические центры распределены примерно равномерно, а между ними формируются зоны экономического влияния; в) линейный тип формируется обычно вдоль русел рек, горных массивов, транспортных магистралей, где система расселения и рисунок размещения экономической деятельности повторяет природный контур, а вокруг них могут формироваться второстепенные центры по соответствующим линейным связям и магистралям;

г) приморско-фасадный тип специфичен для прибрежных регионов с характерной доминантой портовых городов и курортных центров, локализованных вдоль акватории;

д) полицентрический центрально-бассейновый (или бассейновый звездный) тип формируется в регионах развития горнодобывающей промышленности - в нем сочетание экономических центров и городских агломераций формируется в бассейнах дисперсно вокруг центров разработки минерального ресурса;

е) центральный тип (тип фактории) характерен для слабо освоенных территорий, где хозяйственная деятельность локализована в некоторых местах разработки минерального сырья, заготовки древесины, ограниченного земледелия [8].

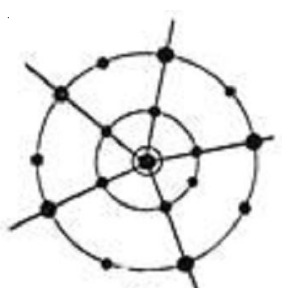

a)

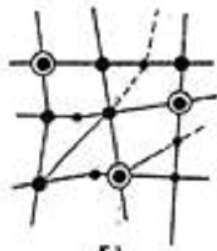

8)

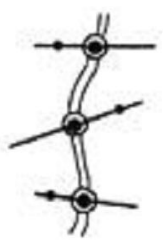

b)
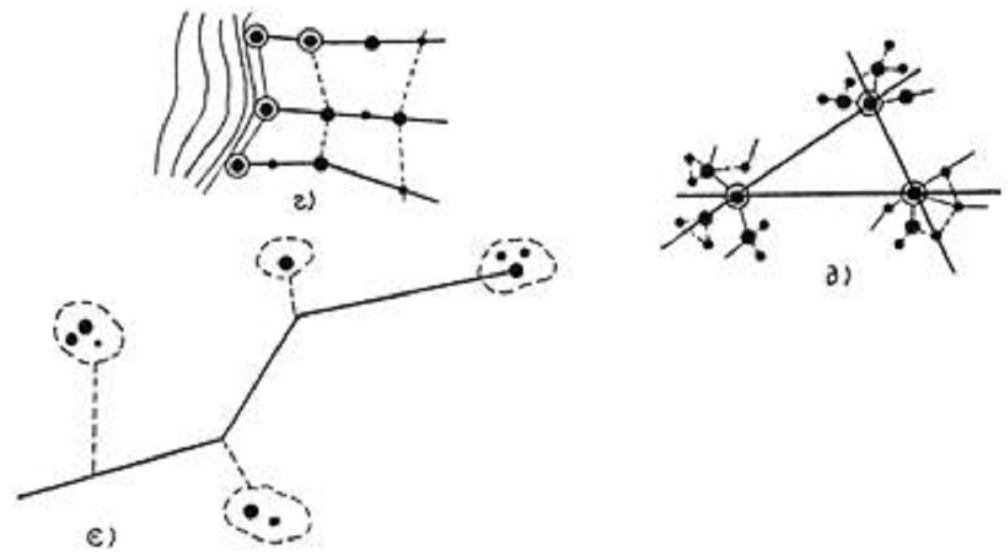

d)

Рис. 1. Типы территориальных структур экономического пространства (по И.М. Майергойзу):

$a$ - центро-периферийный (концентрический); $\sigma$ - полицентрический (квадратно-прямоугольный); 8 - линейный; 2 - приморско-фасадный; $\partial$ - полицентрический центрально-бассейновый; $e$ - центральный

Примечание. Составлено по: [8]. 
Наибольшее распространение и применение имеет центро-периферийная модель. Делимитация центро-периферийной структуры экономического пространства базируется на следующих основополагающих принципах:

1. Объективность и универсальность характера центро-периферийной организации, приоритетность ее влияния на социально-экономическое развитие территории.

2. Полимасштабность - «взаимонаслоение» на одной и той же территории систем локального (местного), субрегионального, регионального, макрорегионального и странового (национального) уровней.

3. Вариативность (множественность) возможности существования наряду с численно преобладающими моноцентрическими территориальными системами еще и бипольных (когда соответствующие функции распределяются между двумя центрами социально-экономической активности), а также полицентрических (с тремя и более организующими территорию «центральными местами») пространственных структур.

4. Устойчивость центро-периферийной организации во времени и одновременно ее изменчивость под влиянием экономической конъюнктуры, реализации новых производственных и инфраструктурных проектов, административных и бизнес-решений, пространственного расширения (либо напротив, «сжатия») периферии (благодаря изменению потенциала центра, модернизации транспортной системы, конкуренции сопредельных «центров») [6].

Таким образом, центро-периферийная организация как устоявшиеся взаимосвязи частей территории - центра, периферии и полупериферии - базируется на их функциональной взаимозависимости, выраженных количественных и качественных социально-экономических различиях и показателях транспортнокоммуникационной доступности (с учетом физических расстояний, наличия и состояния дорожной сети и спектра имеющихся видов транспорта).

Делимитация территориальной центропериферийной структуры предполагает две базовые последовательные операции:

а) идентификация «центров» («центральных мест») в рамках некой очерченной цело- стной территории на основании их многокомпонентного анализа, сопоставления, ранжирования и отбора;

б) делимитация периферийных территорий для каждого из выделенных центров на основании критериев их социально-экономической связанности посредством устойчивых потоков трудовой и культурно-бытовой маятниковой миграции, производственной и административной субординации, а также транспортной доступности.

Идентификация и обоснование «центра» выступает основополагающим моментом исследования всей центро-периферийной структуры и практически предполагает анализ следующих групп параметрических характеристик.

1. Демографо-экстическая группа включает учет:

- численности населения доминирующего населенного пункта, его сопоставление по данному параметру с остальными поселениями анализируемой территории. Здесь применимо правило «ранг - размер» Дж. Зипфа, а ранжирование населенных пунктов региона можно осуществлять как в целом по региону, так и по отдельным относительно обособленным его частям - субрегионам (округам), там, где наряду с общерегиональным центром действует и свой локальный центр (узел) более низкого ранга иерархии;

- удельного веса населения, локализованного в доминирующем населенном пункте, во всей численности населения анализируемой территории, что является основой для выстраивания иерархии населенных пунктов по их людности и степени концентрации населения;

- динамики численности населения доминирующего населенного пункта, его сопоставление по данному параметру с остальными поселениями анализируемой территории, а также со средними по территории значениями.

При этом особую важность, на наш взгляд, имеет показатель сальдо миграции, который отражает миграционную привлекательность региона. Сальдо миграции может существенно разниться по городам и сельским административным районам, что позволяет установить фактические центры притяжения населения, равно как и территории, от- 
куда население бежит. Анализ динамики наиболее целесообразно проводить в динамике за достаточно большой промежуток времени, что позволяет установить долгосрочные тренды демографического развития региона.

2. Административный статус поселения, выраженный в отнесении того или иного населенного пункта к группе городов регионального (областного, краевого, республиканского) подчинения либо в число центров сельских административных районов. Статус гарантирует дополнительную концентрацию бюджетных рабочих мест, миграционную привлекательность, инфраструктурную обустроенность, сравнительно более благоприятные условия для проживания и ведения бизнеса, a соответственно, более высокую роль в центро-периферийной структуре региона.

3. Экономико-локализационная группа показателей, учет которых должен строиться исходя из фактической мезоэкономической специализации и приоритетности («центральности») тех или иных компонент хозяйственной среды. Принимая во внимание ограниченность отечественной статистической базы данных на микрорегиональном и муниципальном уровнях, для отображения особенностей экономического развития региона при идентификации его центра, приоритетное значение в масштабе всего региона имеют следующие индикаторы:

- локализация рабочих мест в сфере управления (абсолютные показатели и удельный вес в общей численности занятых);

- локализация рабочих мест в финансовой сфере (абсолютные показатели и удельный вес в общей занятости);

- локализация головных офисов местного (регионального по генезису) бизнеса и региональных филиалов (отделений) крупного национального и транснационального бизнеса (если таковые имеются).

На субрегиональном (локальном) уровне также значимы в анализе следующие параметры:

- локализация действующих (либо реально строящихся) промышленных предприятий (прежде всего перерабатывающих местное минеральное или сельскохозяйственное сырье, замыкающих на себе сложившиеся сырьевые зоны);
- размещение офисов (усадеб, правлений, контор) промышленных, сельскохозяйственных, торговых, транспортных и иных предприятий;

- локализация сетевых структур розничной торговли, почтовых отделений, а также филиалов и офисов финансово-кредитных и страховых структур;

- размещение предприятий пищевой промышленности межрайонного значения (к примеру, хлебокомбинатов), осуществляющих сбыт в нескольких районах, тем самым снабжающих продуктами питания территорию региона.

Данная группа показателей позволяет не только выявить социально-экономический профиль всего региона и отдельных его центров по представленным в них ведущим предприятиям, действующим в их пределах, но и косвенным образом проследить степень инвестиционной активности и установить пространственную дифференциацию отраслей экономики, прежде всего ориентированных на удовлетворение спроса населения в продуктах местного производства (к примеру, продовольствия).

4. Социально-инфраструктурная группа показателей учитывает:

- размещение образовательных учреждений (либо их филиалов), предоставляющих высшее и среднее профессиональное образование;

- наличие образовательных учреждений, предоставляющих среднее общее образование и формирование образовательных кластеров;

- наличие учреждений здравоохранения межрайонного значения;

- локализация подразделений научно-исследовательских организаций;

- наличие значимых объектов культурно-исторического наследия, музеев, объектов туристско-рекреационной инфраструктуры;

- размещение уникальных современных объектов спортивной и культурно-досуговой инфраструктуры.

5. Транспортно-локализационная группа, в том числе:

- доступность регионального центра для других поселений и сложившихся субрегиональных центров, определяемая через индикатор расстояния (пространственной близости), наличия и состояния транспортной инф- 
раструктуры, обеспечивающей устойчивость сообщения между поселениями;

- степень приближенности к важнейшим транспортно-коммуникационным «коридорам» федерального и межрегионального значения и транспортно-логистическим узлам.

Важным критерием местоположения поселений в центро-периферийной модели экономического пространства выступает их локализация, обеспечивающая примерную равноудаленность от регионального центра и иных (альтернативных) субцентров, а также фактическую доступность современными транспортными средствами (автомобильным сообщением) в пределах 1-1,5 часа пути (6090 км) основного массива населения и хозяйственной инфраструктуры всей центро-периферийной системы. Центральное положение муниципалитета выступает потенциалом для формирования вокруг него емкого и обширного по площади хинтерланда - ареала социально-экономического тяготения территории [9]. Его устанавливают согласно двум критериям - расстоянию и времени в пути от главного административного и социальноэкономического центра территории («центрального места»). При этом на расстоянии до 100 км от центра, то есть непосредственно в зоне его влияния и территориальной близости, размещается ядро центро-периферийной структуры, на дальнейшем удалении - полупериферия и периферия [10].

Идентификация периферии производится с учетом уже выявленного ранее «центра» (поселения, в наибольшей мере выполняющего «центральные» функции) на основании:

- критерия наиболее благоприятной транспортной доступности выявленного «центра» в сопоставлении с иными (альтернативными) центрами;

- фактических сбытовых, сырьевых и сервисных зон локализованных в «центре» предприятий и организаций;

- административных рубежей.

В ситуации, когда лидерство того или иного «центра» неявно, уместна постановка вопроса о полицентричности центро-периферийной системы (либо наличии «рассредоточенного» центра).

При сопоставлении муниципальных административных районов первостепенное вни- мание следует уделять следующим социально-экономическим индикаторам:

1) уровню жизни населения, иллюстрируемому, прежде всего, такими индикаторами, как:

- ввод жилья на 1000 жителей;

- средняя заработная плата;

2) качеству жизни населения, включая благоустройство жилого фонда;

3) институциональной насыщенности числу хозяйствующих субъектов, включая малые предприятия;

4) качественным параметрам производственной активности в профильных отраслях, включая урожайность культур растениеводческой специализации, средний удой молока на одну корову, среднюю яйценосность одной курицы-несушки, средний настриг шерсти с одной овцы, численность племенного крупного рогатого скота (в том числе и в соотношении с общей численностью поголовья);

5) инвестиционной привлекательности, включая общий и душевой объем инвестиций, в том числе бюджетных.

Районы обладают отличительными свойствами своего социально-экономического развития, но в то же время имеют и общие черты географического положения, природных условий, демографической ситуации и расселения, специализации хозяйства. Основываясь на количественных и качественных параметpax, производят группировку схожих, близкорасположенных районов в территориально-экономические округа. Важными критериями такой группировки являются:

1) территориальная близость, которая позволяет объединить соседние районы в единый округ;

2) сходство уровней и тенденций социально-экономического развития, которое определяется на основе количественных индикаторов;

3) общность проблем социально-экономического развития.

При сопоставлении различных по природе социально-экономических индикаторов возможно и необходимо использовать методы бальных оценок и многопризнаковых типологий, посредством которых можно осуществить сводную, итоговую группировку муниципальных образований рассматриваемой территории в пространственно-выраженные иерархи- 
ческие образования центро-периферийной структуры, выявить и обосновать специфику каждого из них.

Изложенный алгоритм изучения неоднородности экономического пространства был применен при делимитации современной центро-периферийной структуры Ростовской области. Ее выделение основано на опорном каркасе населения, представленном городами как узловыми центрами расселения и производства, а также транспортными магистралями как линиями взаимосвязи поселений и территорий.

Исходя из исторически сложившейся схемы расселения, административным и социально-экономическим центром Ростовской области выступает Ростов-на-Дону, концентрирующих более $1 / 4$ населения всей области и благодаря своему выгодному транспортно-географическому положению выступает фокусом транспортных магистралей (железнодорожных, автомобильных, водных по р. Дон и из Азовского моря), связываю- щих его с периферией по радиальным направлениям. Такая линейно-радиальная структура транспортной инфраструктуры вкупе с особенностями расселения и особенностями размещения хозяйства является основой для выделения в пространственной организации Ростовской области модели центро-периферийной структуры в форме трех иерархических уровней: центр полупериферия - периферия.

В состав центра входит, прежде всего, сам город Ростов-на-Дону, концентрирующий в себе значительную часть демографического, трудового, финансового, инвестиционного и производственного потенциала области (рис. 2).

Ростов вместе с прилежащими к нему населенными пунктами образует Ростовскую агломерацию. При этом ряд муниципалитетов (прежде всего города Аксай и Батайск) в силу процессов субурбанизации практически срослись с Ростовом-на-Дону в единое городское пространство, образуя ядро центро-периферий-

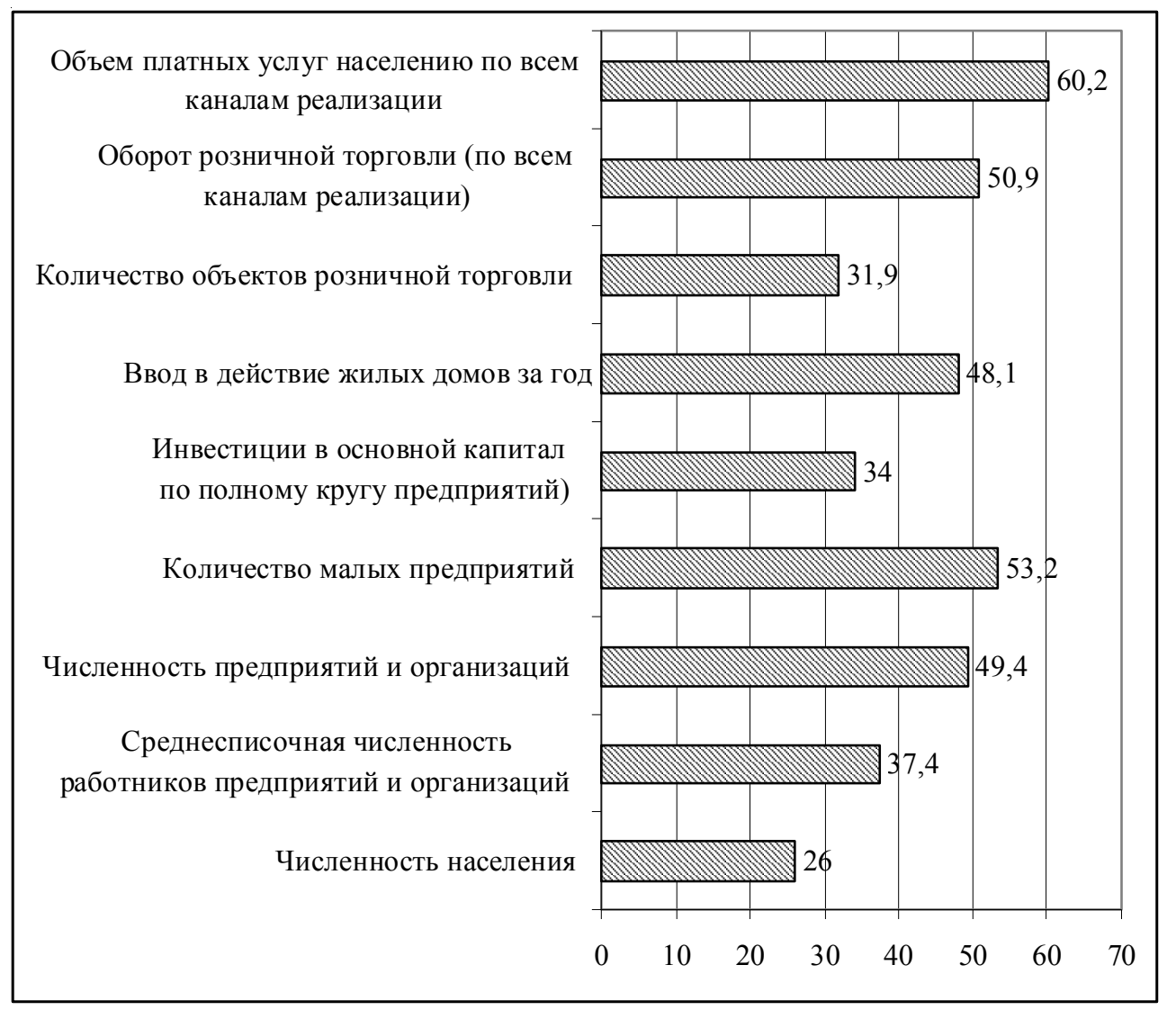

Рис. 2. Доля Ростова-на-Дону в основных социально-экономических параметрах Ростовской области Примечание. Составлено по: [11;15]. 


\section{СОЦИАЛЬНО-ЭКОНОМИЧЕСКОЕ РАЗВИТИЕ РЕГИОНОВ}

ной структуры области. В состав ядра также включаются населенные пункты, находящиеся в ближайшей транспортной доступности от Ростова-на-Дону и связанные с ним тесными миграционными потоками (рис. 3).

Посредством маятниковых трудовых миграций, имеющих центростремительную направленность, как территориальных градиентов центро-периферийной структуры, населенные пункты из ближайшего окружения Ростова-на-Дону напрямую тяготеют к нему, входя в зону его непосредственного социально-экономического влияния. Все они в силу прямой территориальной близости (удаленность от центра в пределах 30-50 км, то есть непосредственно в пригородной зоне) и развитости транспортного сообщения (как автодорог, так и пригородного железнодорожного сообщения) находятся в прямой транспортной доступности от Ростова, являются по отношению к нему административными центрами первого порядка и обладают высокой степенью социально-экономического развития (см. таблицу).

За счет высокой производственной и инвестиционной активности в центральной зоне экономического пространства Ростовской области отмечаются повышенные уровни заработной платы в сравнении с другими муниципальными образованиями, высокий уровень коммунального благоустройства и рост объе- мов строительства недвижимости. Хотя здесь насчитывается всего лишь $5 \%$ предприятий и организаций области, но вклад территориальных образований в экономическое развитие области заметен и адекватен их ресурсному потенциалу. Сельские районы центра демонстрируют высокую урожайность зерновых культур и подсолнечника, а в развитии животноводства специализируются на птицеводстве и молочном скотоводстве.

Полупериферия располагается на удалении до 180-200 км от Ростова-на-Дону в наиболее доступной для автомобильного сообщения (как главного в перевозке грузов и пассажиров внутри области) местности и включает в себя г. Таганрог с муниципальными районами юго-запада Ростовской области, а также муниципальные районы и города Восточного Донбасса - Шахты, Новошахтинск, Красный Сулин, Гуково, Зверево, Каменск-Шахтинский, Донецк, Белая Калитва с соседними муниципальными районами (см. рис. 3). Полупериферийная зона Ростовской области отличается отрицательным сальдо миграции и естественной убылью населения, пониженными уровнями заработной платы и социальных индикаторов в сравнении со среднеобластными данными, более низкой производственной активностью и инвестиционной привлекательностью (см. таблицу).

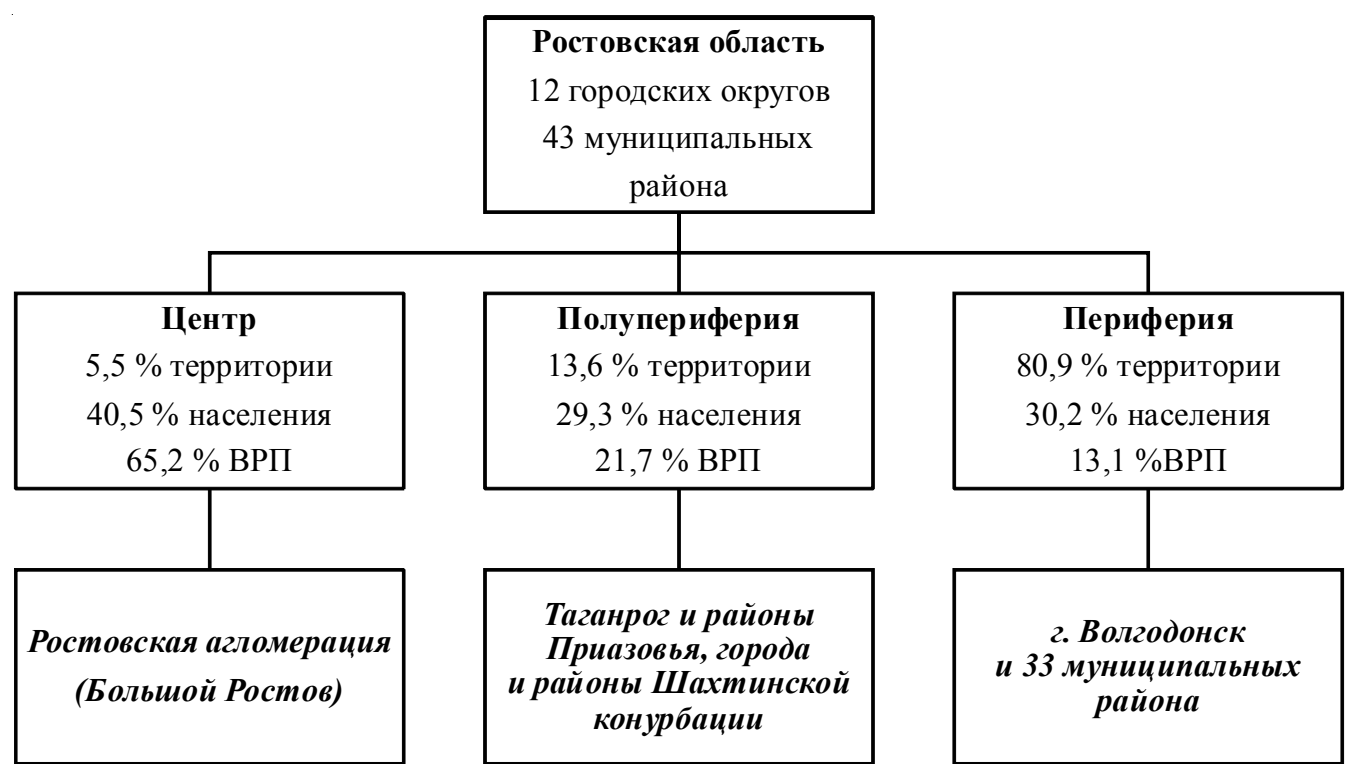

Рис. 3. Центро-периферийная структура экономического пространства Ростовской области Примечание. Составлено по: [11;15]. 
Дифференциация социально-экономического развития пространственных зон центро-периферийной структуры Ростовской области

\begin{tabular}{|l|c|c|c|}
\hline \multicolumn{1}{|c|}{ Социально-экономические индикаторы } & \multicolumn{2}{|c|}{ Роны центро-периферийной структуры } \\
\cline { 2 - 4 } & Центр & Периферия & Полупериферия \\
\hline Темп прироста численности населения, 2013-2016 гг., \% & 5,3 & $-4,3$ & $-5,2$ \\
\hline $\begin{array}{l}\text { Соотношение среднемесячной заработной платы в муниципальном об- } \\
\text { разовании со среднеобластным уровнем, раз }\end{array}$ & 0,96 & 0,8 & 0,73 \\
\hline $\begin{array}{l}\text { Доля занятых в финансовом секторе муниципального образования от } \\
\text { общеобластной численности занятых в данном секторе, \% }\end{array}$ & 78,6 & 12,1 & \\
\hline $\begin{array}{l}\text { Доля занятых в сфере управления муниципального образования от об- } \\
\text { щеобластной численности занятых в данной отрасли, \% }\end{array}$ & 56,7 & 19,6 & 23,7 \\
\hline $\begin{array}{l}\text { Доля численности предприятий в общеобластной их величине, 2013 г., } \\
\text { \% }\end{array}$ & 62,8 & 19,5 & 17,7 \\
\hline Ежегодный ввод жилья на 1 о00 жителей, в среднем в 2006-2013 гг., м ${ }^{2}$ & 748 & 219 & 193 \\
\hline $\begin{array}{l}\text { Отношение величины инвестиции на душу к среднеобластной величине, } \\
\text { раз }\end{array}$ & 1,58 & 1,14 & 0,97 \\
\hline Доля жилищного фонда, обеспеченного коммунальными благами, \%: & & & \\
\hline водопровод & 80 & 68 & 63 \\
\hline канализация & 79 & 61 & 52 \\
\hline центральное отопление & 89 & 68 & \\
\hline газоснабжение & 88 & 79 & 92 \\
\hline горячее водоснабжение & 70 & 43 & 41 \\
\hline
\end{tabular}

Примечание. Составлено по: [11;15].

В пространственной структуре полупериферийной зоны Ростовской области четко выделяются два ядра с тяготеющими к ним группировками районов: на юго-западе это Таганрог, который обслуживает своим социально-экономическим влиянием районы Приазовья (кроме Азовского района, который по территориальной близости и социально-экономическим связям ориентируется на Ростовна-Дону), а также Шахтинская конурбация с доминирующей ролью города Шахты. Города, выступающие центрами полупериферийной зоны, отличаются несколько меньшими масштабами естественной и механической убыли населения в сравнении с другими полупериферийными территориями, концентрируют в своих пределах около 13 \% численности предприятий и организаций области (в сравнении с $7 \%$ на остальной части полупериферийной зоны) и имеют развитый промышленный комплекс. Однако, в силу ограниченности бюджетных средств и затянувшейся экономической депрессии, уровень развития жилищной и социальной инфраструктуры, жилищного строительства, производства промышленной продукции и заработной платы здесь заметно ниже [9]. В то же время локальные центры полупериферии выступают социально-эконо- мическими аттрактами для окружающих муниципальных районов, осуществляя их торговое, медицинское, культурное, спортивное, образовательное, транспортное обслуживание, притягивая рабочую силу на предприятия.

Периферийная зона Ростовской области включает в себя все районы севернее Каменского, к востоку от Тацинского, Усть-Донецкого и Багаевского, к югу от Мартыновского и Волгодонского, все районы к юго-востоку, начиная от Кагальницкого [16]. Периферия Ростовской области является самой неоднородной пространственной структурой, и ее узловыми ядрами (центрами периферии) выступают города Миллерово, Морозовск, Зерноград, Сальск, пгт. Зимовники, ст. Вешенская, но при ведущей роли г. Волгодонска как социальноэкономического центра этой части области (см. рис. 3). Периферия отличается наибольшей удаленностью от Ростова-на-Дону (максимально до 400 км на север и до 500 км на восток) и наименьшей транспортной доступностью областного центра. Вследствие ряда факторов уровень развития экономики и социальной сферы здесь заметно ниже, чем в других частях области.

Они имеют затяжную депопуляцию в силу как миграционного оттока, так и есте- 


\section{СОЦИАЛЬНО-ЭКОНОМИЧЕСКОЕ РАЗВИТИЕ РЕГИОНОВ}

ственной убыли населения, низкий уровень производственной активности и инвестиционной привлекательности, типично аграрную структуру экономики, низкий уровень доходов населения и недостаточную степень коммунального благоустройства населенных пунктов. В структуре сельского хозяйства этих районов зачастую преобладает животноводство над растениеводством, представленное развитием овцеводства и козоводства. Промышленные предприятия либо отсутствуют вообще, либо представлены незначительными по мощности объектами пищевой промышленности, металлообработки и ремонта сельскохозяйственной техники, промышленности строительных материалов, продукция которых имеет районообслуживающее значение.

Районы периферии территориально образуют два ареала - северный и южный. Периферийные районы севера отличаются несколько более значительным демографическим кризисом, но активным жилищным строительством. Районы юга периферии в силу интенсивной газификации их населенных пунктов в последние два десятилетия демонстрируют более высокий уровень коммунального благоустройства. Оба ареала размещаются в наименее благоприятных климатических условиях (на севере более низкие температура, на юге недостаточное увлажнение, близкое к полупустынной природной зоне, и значительное распространение засух, суховеев, сильных ветров), что вкупе с развитием водной, а на юге еще и ветровой эрозии являются факторами, ограничивающими эффективность сельскохозяйственного производства, являющегося главной отраслью в экономическом профиле.

Главными негативными чертами социально-экономического развития районов периферии Ростовской области выступают:

- аграрный тип и традиционные условия ведения хозяйства, которые требуют высоких издержек производства;

- выраженный отток населения и доминирование в системе расселения малых и мельчайших поселений с неразвитой социальной инфраструктурой;

- замкнутость, отсутствие развитых коммуникаций и высокие транспортные издержки;
- фрагментарность и во многом анклавный характер местных рынков, низкий платежеспособный спрос населения [16].

Таким образом, экономическое пространство региона выступает как среда экономических отношений, то есть совокупность взаимодействий между экономическими субъектами, расположенными на конкретной территории и развивающимися во времени. Оно характеризуется неоднородностью, выражающейся в различной степени его концентрации и обусловленной структурированностью взаимодействия эндогенных факторов производства - природного и человеческого, институционального и информационного, организационного и техникотехнологического. Асинхронность экономических процессов, различный уровень конкурентоспособности хозяйствующих субъектов, задействованных в этих процессах, а также их индивидуальное восприятие институциональной среды обусловливают неоднородность экономического пространства региона.

Территориальная структура экономического пространства может соответствовать центро-периферийной модели его устройства. При этом обычно выделяют три пространственно выраженных территориальных образования - экономический и административный центр, по мере удалении от которого степень хозяйственной активности и социально-экономического благополучия снижается в пределах районов полупериферии и периферии, формирующих хинтерланд центра. Идентифицировать, описать и провести делимитацию этих пространственных структур возможно посредством системы социально-экономических индикаторов, позволяющих выявить особенности и определить перспективные пути развития всего региона.

\section{СПИСОК ЛИТЕРАТУРЫ}

1. Айзард, У. Методы регионального анализа: введение в науку о регионах / У. Айзард. - М. : Прогресс, 1966. -660 c.

2. Бияков, О. А. Теория экономического пространства: методологический и региональный аспекты / О. А. Бияков. - Томск : Изд-во Том. ун-та, 2004. $-152 \mathrm{c}$.

3. Валинурова, Л. С. Теории пространственной и региональной экономики / Л. С. Валинурова, 
О. Б. Казакова, Л. Г. Ахтариева. - Уфа : БАГСУ, 2012. $-96 \mathrm{c}$.

4. Гранберг, А. Г. Основы региональной экономики / А. Г. Гранберг. - М. : ГУ-ВШЭ, 2004. $495 \mathrm{c}$.

5. Гульбасов, А. В. Пространственный подход в экономической науке / А. В. Гульбасов, В. В. Чекмарев. - Кострома ; Смоленск : Универсум, 2005. $-76 \mathrm{c}$.

6. Загитова, Л. Современные особенности поляризации экономического пространства России / Л. Загитова // Сегодня и завтра Российской экономики. -2012 . - № 56. - С. 59-62.

7. Иншаков, О. В. Экономическое пространство и пространственная экономика / О. В. Иншаков // Пространственная экономика. - 2006. - № 2. C. 28-38.

8. Маергойз, И. М. Территориальная структура хозяйства / И. М. Маергойз. - Новосибирск : Наука, Сибирское отделение, 1986. - 218 с.

9. Миргородская, Е. О. Детерминанты комфортности бизнес-среды региона: формирование пространственного образа региона / Е. О. Миргородская, С. В. Сытник // TERRA ECONOMICUS. 2012. - Т. 10, № 4, ч. 3. - С. 100-104.

10. О полицентричности пространственной и территориальной структуры региона / Е. Н. Кадышев, И. В. Петрова, Н. А. Ращепкина, Д. С. Федяева // Региональная экономика: теория и практика. 2015. - № 8. - C. 15-26.

11. Основные показатели социально-экономического положения муниципальных образований // Территориальный орган Федеральной службы государственной статистики по Ростовской области (Ростовстат). - Электрон. текстовые дан. - Режим доступа: http://rostov.gks.ru/wps/wcm/connect/rosstat_ts/ rostov/ru/municipal statistics/main indicators/ (дата обращения: 12.04.2017). - Загл. с экрана.

12. Перру, Ф. Экономическое пространство: теория и приложения / Ф. Перру ; пер. с англ. А. П. Горюнова // Пространственная экономика. - 2007. № 2. - C. 77-93.

13. Портер, М. Международная конкуренция. Конкурентные преимущества стран / М. Портер. М. : Междунар. отношения, 1993. - 896 с.

14. Решиев, С. С. Основные направления развития и подходы в теории региональной экономики в развитых западных странах / С. С. Решиев // Региональная экономика: теория и практика. 2010. - № 33. - C. 58-68.

15. Сравнительные показатели социально-экономического положения городских округов и муниципальных районов Ростовской области - 2015 : стат. сб. - Ростов н/Д : Ростовстат, 2016. - 392 с.

16. Сухинин, С. А. Социально-экономическое районирование северо-восточной периферии Ро- стовской области в интересах формирования территориально сбалансированной концепции ее развития / С. А. Сухинин // Региональная экономика: теория и практика. -2015 . - № 21. - С. 36-47.

\section{REFERENCES}

1. Izard W. Metody regionalnogo analiza: vvedenie v nauku o regionakh [Methods of Regional Analysis: Introduction to the Science of Regions]. Moscow, Progress Publ., 1966. 660 p.

2. Biyakov O.A. Teoriya ekonomicheskogo prostranstva: metodologicheskiy i regionalnyy aspekty [Theory of Economic Space: Methodological and Regional Aspects]. Tomsk, Izd-vo Tom. un-ta, 2004. $152 \mathrm{p}$.

3. Valinurova L.S., Kazakova O.B.,Akhtarieva L.G. Teorii prostranstvennoy $i$ regionalnoy ekonomiki [Theories of Spatial and Regional Economics]. Ufa, BAGSU Publ., 2012. 96 p.

4. Granberg A.G. Osnovy regionalnoy ekonomiki [Basics of Regional Economy]. Moscow, GU-VShE Publ., 2004. 495 p.

5. GulbasovA.V.,Chekmarev V.V.Prostranstvennyy podkhod v ekonomicheskoy nauke [Spatial Approach in Economics]. Kostroma; Smolensk, Universum Publ., 2005.76 p.

6. Zagitova L. Sovremennye osobennosti polyarizatsii ekonomicheskogo prostranstva Rossii [Modern Features of the Polarization of the Economic Space of Russia]. Segodnya i zavtra Rossiyskoy ekonomiki, 2012, no. 56. pp. 59-62.

7. Inshakov O.V. Ekonomicheskoe prostranstvo i prostranstvennaya ekonomika [Economic Space and Spatial Economics]. Prostranstvennaya ekonomika, 2006, no. 2, pp. 28-38.

8. Maergoyz I.M. Territorialnaya struktura khozyaystva [The Territorial Structure of the Economy]. Novosibirsk, Nauka Publ., 1986. 218 p.

9. Mirgorodskaya E.O., Sytnik S.V. Determinanty komfortnosti biznes-sredy regiona: formirovanie prostranstvennogo obraza regiona [Determinants of Comfortability of Business Environment of the Region: Formation of a Spatial Image of the Region]. TERRA ECONOMICUS, 2012, vol. 10, no. 4, pp. 100-104.

10. Kadyshev E.N., Petrova I.V., Rashhepkina N.A., Fedyaeva D.S. O politsentrichnosti prostranstvennoy i territorialnoy struktury regiona [On the Polycentricity of the Spatial and Territorial Structure of the Region]. Regionalnaya ekonomika: teoriya i praktika, 2015, no. 8, pp. 15-26.

11. Osnovnye pokazateli sotsialnoekonomicheskogo polozheniya munitsipalnykh obrazovaniy [The Main Indicators of the SocioEconomic Status of the Municipalities]. Territorialnyy 
organ Federalnoy sluzhby gosudarstvennoy statistiki po Rostovskoy oblasti (Rostovstat) [The Territorial Body of the Federal State Statistics Service for the Rostov Region]. URL: http://rostov.gks.ru/wps/wcm/ connect/rosstat_ts/rostov/ru/municipal_statistics/ main_indicators/. (accessed April 12, 2017).

12. Perru F. Ekonomicheskoe prostranstvo: teoriya i prilozheniya [Economic Space: Theory and Applications]. Prostranstvennaya ekonomika, 2007, no. 2, pp. 77-93.

13. Porter M. Mezhdunarodnaya konkurentsiya. Konkurentnye preimushchestva stran [International Competition. Competitive Advantages of the Countries]. Moscow, Mezhdunarodnye otnosheniya Publ., 1993. 896 p.

14. Reskhiev S.S. Osnovnye napravleniya razvitiya i podkhody v teorii regionalnoy ekonomiki v razvitykh zapadnykh stranakh [Main Directions of Development and Approaches in the Theory of
Regional Economy in Western Developed Countries]. Regionalnaya ekonomika: teoriya i praktika, 2010, no. 33, pp. 58-68.

15. Sravnitelnye pokazateli sotsialnoekonomicheskogo polozheniya gorodskikh okrugov i munitsipalnykh rayonov Rostovskoy oblasti - 2015: stat. $s b$. [Comparative Indicators of Socio-Economic Status of Urban Districts and Municipal Districts of the Rostov Region - 2015: Statistical Yearbook]. Rostov-on-Don, Rostovstat Publ., 2016.392 p.

16. Sukhinin S.A. Sotsialno-ekonomicheskoe rayonirovanie severo-vostochnoy periferii Rostovskoy oblasti $\mathrm{v}$ interesakh formirovaniya territorialno sbalansirovannoy kontseptsii ee razvitiya [Socio-Economic Zoning of the Northeastern Periphery of the Rostov Region in the Interests of Forming a Territorially Balanced Concept of Its Development]. Regionalnaya ekonomika: teoriya $i$ praktika, 2015, no. 21, pp. 36-47.

\section{Information about the Authors}

Elena O. Mirgorodskaya, Doctor of Sciences (Economics), Professor, Head of Department of Economic Theory and Entrepreneurship, Don State Technical University, Sotsialisticheskaya St., 162, 344022 Rostov-on-Don, Russian Federation, emirgorod@mail.ru.

Sergey A. Sukhinin, Candidate of Sciences (Pedagogy), Associate Professor, Department of Economic Theory and Entrepreneurship, Don State Technical University, Sotsialisticheskaya St., 162, 344022 Rostov-on-Don, Russian Federation, suhmax@mail.ru.

\section{Информация об авторах}

Елена Олеговна Миргородская, доктор экономических наук, профессор, заведующая кафедрой экономической теории и предпринимательства, Донской государственный технический университет, ул. Социалистическая, 162, 344022 г. Ростов-на-Дону, Российская Федерация, emirgorod@mail.ru.

Сергей Александрович Сухинин, кандидат педагогических наук, доцент кафедры экономической теории и предпринимательства, Донской государственный технический университет, ул. Социалистическая, 162, 344022 г. Ростов-на-Дону, Российская Федерация, suhmax@mail.ru. 